\title{
THE DISTRIBUTION OF ONYCHOPHORA IN NEW GUINEA AND NEIGHBORING ISLANDS*
}

\author{
By Charles T. Brues
}

\author{
Biological Laboratories, Harvard University
}

Just half a century has elapsed since the presence of Onychophora in the Papuan area was first recognized. In 1898 Willey described Peripatus nove-britannia from New Britain and since then eight others have been added from New Guinea and other adjacent islands. All of these belong to the genus Paraperipatus, but as in the dominant neotropical genera Peripatus and Macroperipatus, the species are closely similar. However, as they show recognizable and apparently constant structural differences they must be accorded specific or at least subspecific rank. In 1931 Leloup proposed a new name for the whole group of Papuan species, which he designated as Paraperipatus leopoldi as a patriotic gesture to the Belgian king. This nomenclatorial faux pas was first noticed publicly by Brongermsa ('32) who placed P. leopoldi as a synonym of $P$. papuensis Sedgwick. The latter is the first species described from New Guinea and furthermore the types came from the Arfak mountain range not far from the locality where Leloup's types were obtained. However, if several species are recognized this synonomy must remain doubtful.

During his stay as a military officer in New Guinea, Dr. P. J. Darlington of the Museum of Comparative Zoology collected three specimens of Paraperipatus in the Bismarck range of the central mountain system near latitude $145^{\circ} \mathrm{E}$. They were taken at two elevations on Mount Wilhelm which rises to a height of 15,400 feet, first at an altitude of $8000 \mathrm{ft}$. in the forest below timberline and again, in moss, at 10,000 $\mathrm{ft}$. which is above timber-line. This is not very far from the type locality of $P$. lorentzi. There are two males, each with 21 pairs of legs and a single female with 22 pairs of legs. In this

* Published with a grant from the Museum of Comparative Zoology. 
and in the size and distribution of the integumentary papillæ they agree closely with the original description of Horst ('10). I have previously recorded $P$. lorentzi from the Arfak mountains in western New Guinea on the basis of specimens sent me many years ago by Frederick Muir (Brues '21). These western individuals appear to approach $P$. stresemanni in having 23 pairs of legs in all three female specimens. They are now in the collections of the Museum of Comparative Zoology together with those more recently obtained by Dr. Darlington. The accompanying outline map shows the present known distribution of the Papuan Paraperipatus. ${ }^{1}$

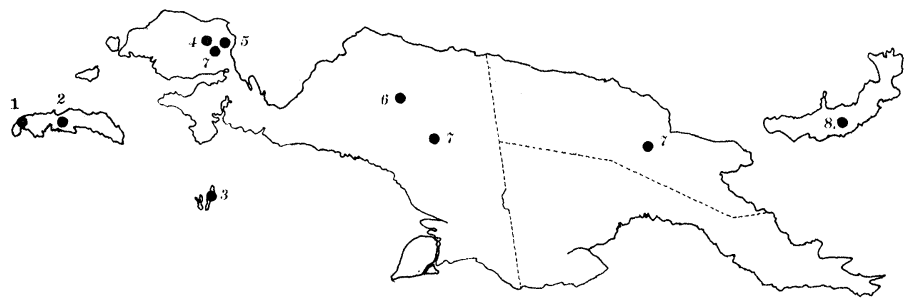

Fig. 1. Map showing the distribution of Paraperipatus in the Papuan area. $1, P$. ceramensis (Ceram); 2, P. stresemanni (Ceram); 3, P. keiensis (Great Key Island) ; 4, P. papuensis (New Guinea); 5, P. leopoldi (New Guinea) ; 6, P. vanheurni (New Guinea) ; 7, P. lorentzi (New Guinea); 8, P. novce-britannice (New Britain).

It is clear that they occur very generally throughout the area, but the scarcity of records and paucity of specimens indicates that they are by no means abundant. In New Guinea they seem to be restricted to high altitudes, although this is not true of the neighboring smaller islands.

\section{Taxonomic ReFerences to Paraperipatus}

Bouvier, E. L. 1914. Un nouveau Paraperipatus de Ceram. Bull. Mus. Hist. Nat., Paris, vol. 20, pp. 222-226.

Brongermsa, L. D. 1932. Suppression of the Name Paraperipatus leopoldi Leloup. Entom. Ber. s'Gravenhage, vol. 9, pp. 410-411.

Brues, C. T. 1921. On Paraperipatus lorentzi Horst and other Species of the Genus from New Guinea and Ceram. Psyche, vol. 28, pp. 50-53, $1 \mathrm{pl}$.

1 The type locality of $P$. schultzei Heymons is too vaguely indicated to place it on the map with full assurance. 
Heymons, R. 1912. Eine neue Peripatusart (Paraperipatus schultzei) aus New Guinea. SB. Gesellsch. naturf. Fr., Berlin, Jahrg. 1912, pp. 215-222.

Honst, R. 1910. Paraperipatus lorentzi Horst, a new Peripatus from Dutch New Guinea. Notes Leyden Mus., vol. 32, pp. 217-218.

Horst, R. 1911. Paraperipatus lorentzi nov. sp. Rés. Expéd. Sci. Neerlandaise à la Nouvelle Guinée, vol. 9, pt. 2, Zool., pp. 149-154.

Leloup, E. 1931. Paraperipatus leopoldi nom. nov. Mém. Mus. Roy. Hist. Nat. Belgique, Hors Sér., vol. 2, fasc. 9, pp. 3-16, 1 pl.

Muir, F., and J. C. Kershaw. 1909. Peripatus ceramensis n. sp. Quart. Journ. Micro. Sci., vol. 53, pp. 737-740, pl. 19.

SedqwiCK, A. 1910. Peripatus papuensis. Nature, vol. 83, pp. 369-370. Willey, A. 1898. On Peripatus nova-britannice, sp. n. Ann. Mag. Nat. Hist. (7), vol. 1, pp. 286-287.

Another Record for Mantispa interrupta Say.-A few weeks ago Mr. F. R. Burrill gave me a fine, fresh specimen of Mantispa interrupta Say which he had taken in Lincoln on foliage of scrub oak, September 26, 1948. Examination of the collection in the Museum of Comparative Zoology revealed just one other Massachusetts specimen, which had been found at the Blue Hill Observatory, a few years ago, by Dr. C. F. Brooks, on Sept. 16, during a strong south wind. The new record suggests that this interesting Neuropteron may be a member of the fauna of this State. Mr. Burrill's specimen has been deposited in the M.C.Z.-Norman S. BaIley, Boston University, Department of Biology. 

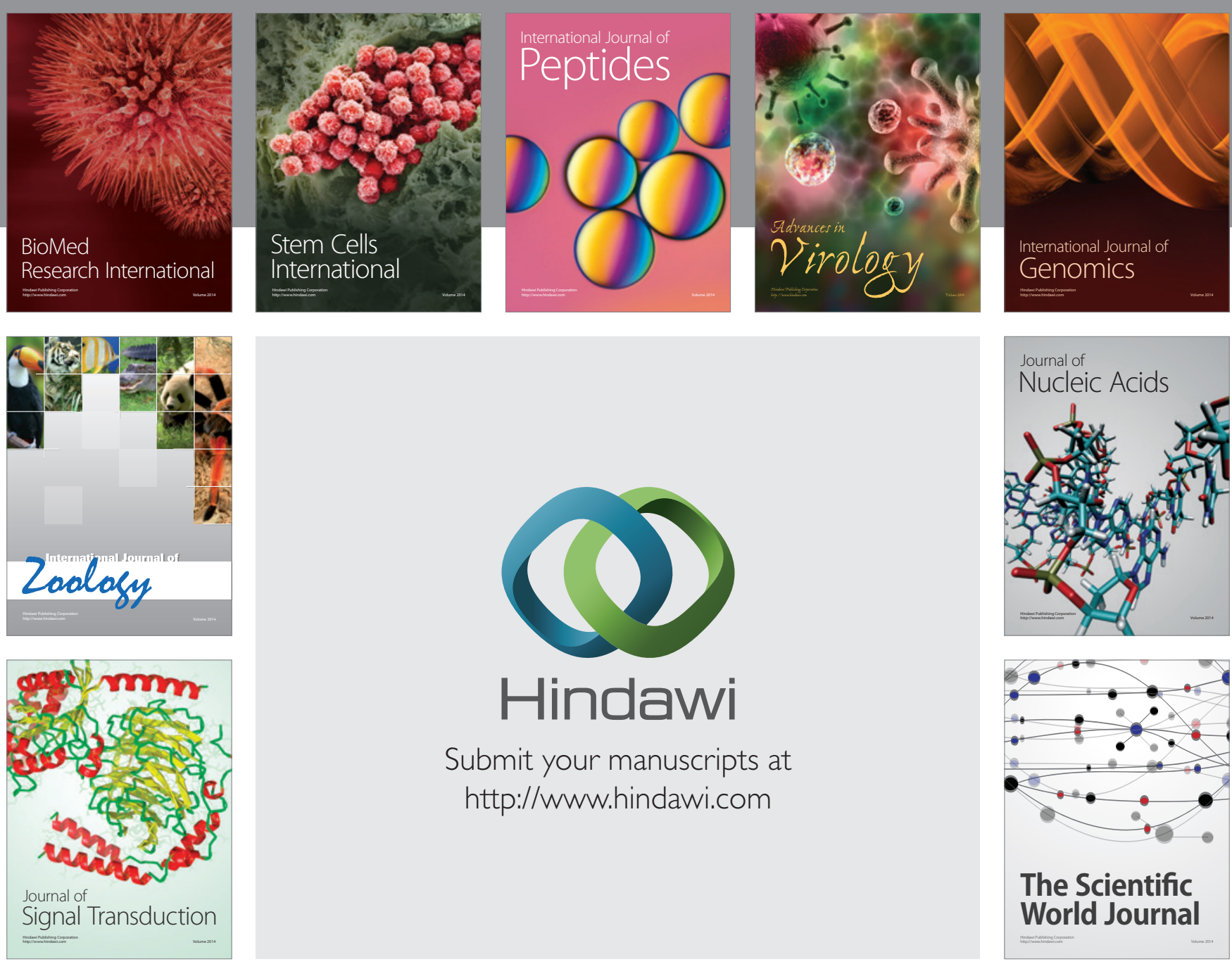

Submit your manuscripts at

http://www.hindawi.com
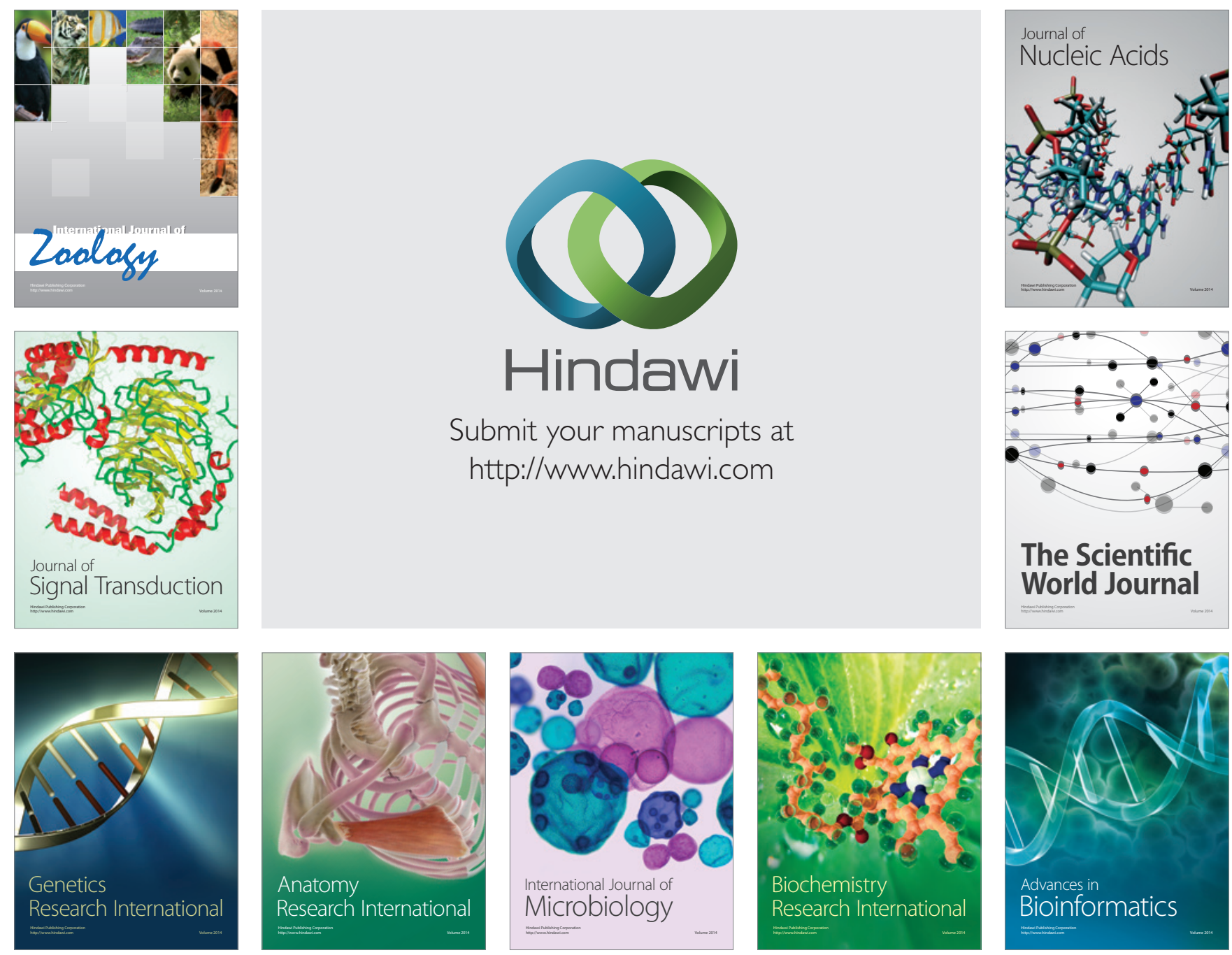

The Scientific World Journal
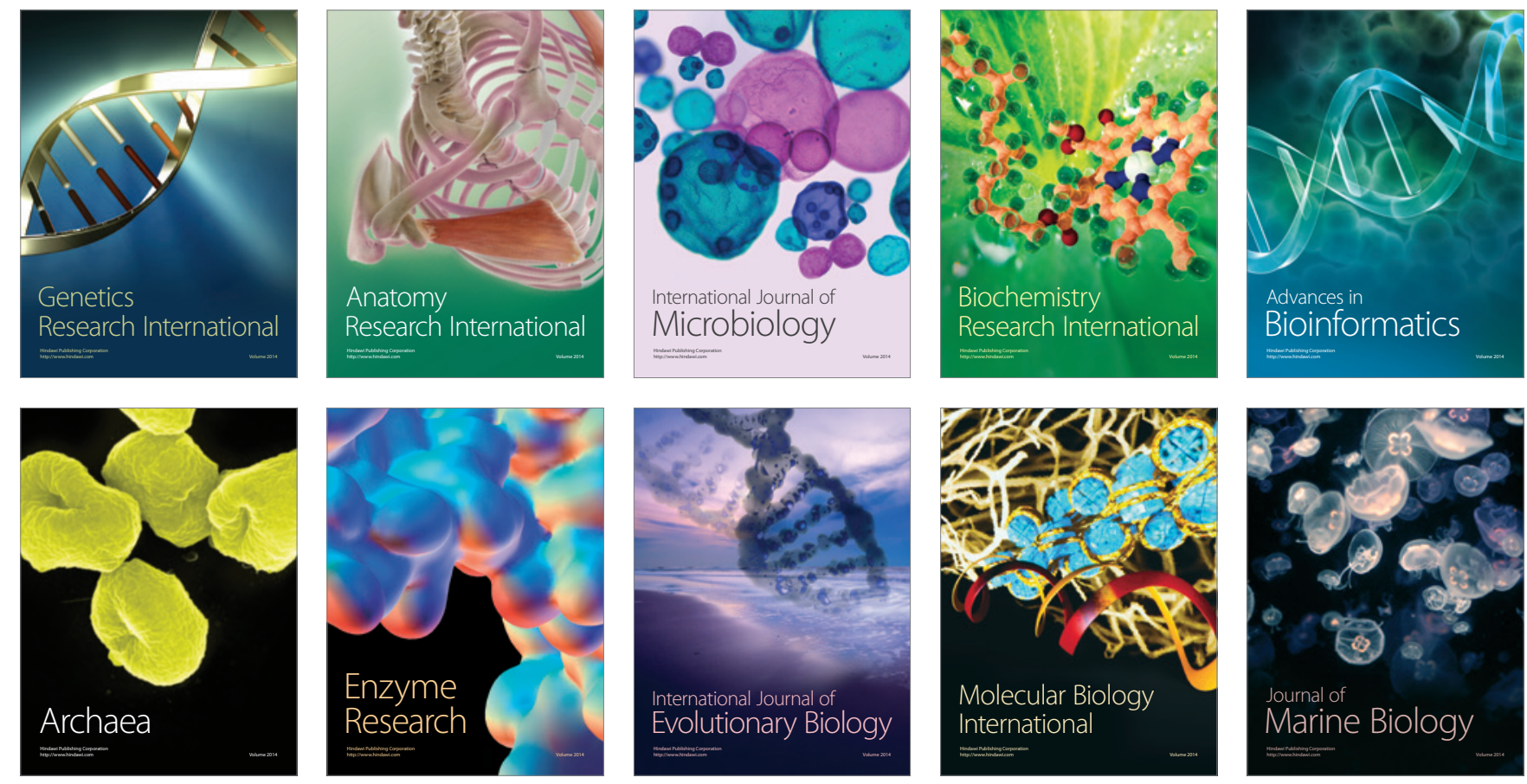